\title{
Towards optimizing caesarean section: a five-year review of caesarean sections at a Southern Nigeria hospital
}

\author{
Nkencho Osegi, Olakunle I. Makinde*
}

Department of Obstetrics and Gynecology, Federal Medical Centre, Yenagoa, Bayelsa State, Nigeria

Received: 18 October 2019

Accepted: 19 November 2019

\section{*Correspondence:}

Dr. Olakunle I. Makinde,

E-mail: olakunleife@gmail.com

Copyright: (C) the author(s), publisher and licensee Medip Academy. This is an open-access article distributed under the terms of the Creative Commons Attribution Non-Commercial License, which permits unrestricted non-commercial use, distribution, and reproduction in any medium, provided the original work is properly cited.

\begin{abstract}
Background: Monitoring caesarean sections at hospital level is essential to reduce unnecessary caesarean sections while still ensuring adequate access to caesarean section. This study was conducted to determine the caesarean section rate and indications for caesarean section at the study centre and provide objective data for institutional interventions towards reducing unnecessary caesarean sections in the centre.

Methods: A retrospective descriptive study of patients that had caesarean sections between $1^{\text {st }}$ January 2013 and $31^{\text {st }}$ December 2017 at the Federal Medical Centre, Yenagoa, Nigeria. Data were analyzed using Statistical Package for Social Sciences version 22.

Results: There were 5,793 deliveries and 1,654 were by caesarean section. The average caesarean section rate was $28.6 \%$. The leading indications for caesarean section were cephalopelvic disproportion (26.6\%), previous cesarean section (18.2\%), suspected fetal distress (11.2\%), severe preeclampsia/eclampsia (7.9\%), obstructed labour (6\%), and breech presentation $(5.9 \%)$.

Conclusions: The $28.6 \%$ caesarean section rate in this study falls within a widely varied rate across Nigeria at hospital level but is comparable to rates within the south-south geopolitical zone of Nigeria. The leading indications for caesarean section are modifiable, thus there is room for institutional intervention to reduce unnecessary caesarean sections. Collaborative research between institutions is required to assess peculiar regional determinants of caesarean section towards developing suitable interventions to reduce unnecessary caesarean sections regionally.
\end{abstract}

Keywords: Caesarean section rate, Clinical Interventions, Indications, Maternal outcome, Non-clinical interventions

\section{INTRODUCTION}

Caesarean section dates back in history to the era when the abdomen of dying or dead women were cut open to save a baby or avoid burying the baby with the mother. During 600 BC, Roman law; Lex Regia and later Lex caesarea required that a foetus be removed before the mother is buried. ${ }^{1}$ Caesarean section has however evolved to become an alternative to vaginal delivery that saves the lives of the mother and/or the foetus in the face of impending danger, compromise and immediate threat to life. It is one of the components of comprehensive emergency obstetric care. ${ }^{2}$

As caesarean section became increasingly safe and comfortably performed by trained doctors, the number of procedures done for nonmedical and medically disputable indications has increased. When compared to vaginal delivery, caesarean section increases hospital stay and cost incurred by the patient, and though rare, it is associated with a higher risk of maternal and perinatal morbidity and mortality. There are also significant long- 
term consequences on a woman's obstetric future after a caesarean section. ${ }^{3,4}$ Maternal and perinatal deaths following caesarean section are higher in developing countries especially in Africa. ${ }^{5}$ Therefore, the risk associated with an unnecessary caesarean section can easily outweigh any intended benefit especially in low resource settings. In 1985, the World Health Organization (WHO) stated that "there is no justification for any region to have caesarean section rates higher than $10-15 \%$ ". 6,7 By the beginning of the $21^{\text {st }}$ century however, caesarean section rates has risen far above $10-15 \%$ in many regions of the world especially in middle and high income countries. $^{7,8}$ The factors driving this continuing increase in caesarean section rates; both intrapartum and planned caesarean sections are complex and multifactorial, and includes health systems factors, health care provider factors, patient factors and social factors. . $^{6-11}$

In 2014, regional analysis of caesarean section rate at population level showed $40.5 \%$ in Latin America and Caribbean, $32.3 \%$ in North America, $25.0 \%$ in Europe, $19.2 \%$ in Asia, $31.1 \%$ in Oceania, and $32.3 \%$ in Australia and New Zealand, but in Africa, with countries like Rwanda, Zambia and Nigeria having rates as low $7.1 \%$. $3.0 \%$ and $2.0 \%$ respectively, the region recorded an average rate of $7.3 \% .^{8}$ According to $\mathrm{WHO}$, a caesarean section rate at population level below $10 \%$ suggests underutilization of the benefit of caesarean section in reducing maternal and neonatal mortality. ${ }^{7}$ Caesarean section rates at hospital level also defer within and across regions, and are determined by the peculiar characteristics of the population being served, the hospital's capability, and clinical management protocols. ${ }^{6,7}$ In Nigeria, hospital level caesarean section rates in the last two decades ranged between $5.39 \%$ and $40.1 \%$. In teaching hospitals, documented caesarean section rate was $30.3 \%$ in Port Harcourt, $25.6 \%$ in Calabar, $27.6 \%$ in Enugu, $18.5 \%$ in Nnewi, $16.4 \%$ in Abakaliki, $11.3 \%$ in Sokoto, $21.4 \%$ in Abuja, 24.5\% in Zaria, $19.8 \%$ in Gombe, $11.8 \%$ in Maiduguri, $17.69 \%$ in Birnin Kudu, 20.3\% in Birnin Kebbi, 32.9\% in Sagamu, and $40.1 \%$ in Lagos. ${ }^{12-25}$ In general hospitals, $10.4 \%$ was documented in Awka and 5.39\% in Calabar, while a private hospital in Jos recorded $8.9 \% .^{26-28}$ This trend exists despite a population level rate as low as $2 \%$, suggesting that assess to caesarean section is skewed; whereas a lot of women lack access to caesarean section to save their lives and that of their babies, some might be undergoing unnecessary procedures. ${ }^{8,29}$ While more effort is required to increase access to caesarean section in Nigeria, interventions (clinical and nonclinical) are also needed at local, regional and national levels to reduce unnecessary caesarean sections. ${ }^{30,31}$ Non-clinical interventions including adherence to evidence based recommendations on management of labour and pregnancy complications, mandatory second opinion, audits and feedbacks have been found to be effective. ${ }^{32-34}$ Spong et al, highlighted clinical interventions addressing common indications for primary caesarean section that are modifiable to achieve vaginal delivery with good outcomes. ${ }^{35}$

The aim of this study was to determine the caesarean section rate and the indications for caesarean section at the Federal Medical Centre, Yenagoa, and to provide objective data for institutional interventions towards reducing unnecessary caesarean sections in the centre while still ensuring adequate access to caesarean sections.

\section{METHODS}

\section{Study design and setting}

A retrospective descriptive study of patients that had caesarean sections between $1^{\text {st }}$ January, 2013 and $31^{\text {st }}$ December, 2017 at the Federal Medical Centre, Yenagoa, Nigeria was conducted. Federal Medical Centre, Yenagoa is a tertiary level health facility in Yenagoa the capital city of Bayelsa State in the south-south geopolitical zone of Nigeria. An average of 1200 deliveries is conducted annually. Patients visit the hospital primarily, and the hospital also serves as a referral hospital to the entire primary and secondary level health facilities in the state; to private hospitals in Yenagoa and its environs, and to traditional birth attendants in Yenagoa and its environs. The Obstetrics unit of the hospital has a total of 41 beds. There are 2 post-natal wards that separate women who have had vaginal delivery from those who had caesarean section with 10 beds and 12 beds respectively. Antenatal ward has 10 beds and the labour ward has 9 beds. Each ward is open to a central nurses' station. There is an operating theatre within the obstetrics and gynaecology complex.

Ethical approval was not required for this type of study.

\section{Inclusion criteria}

- All patients that delivered by caesarean section between $1^{\text {st }}$ January, 2013 and $31^{\text {st }}$ December, 2017 in the records of the Federal Medical Centre, Yenagoa were included in the study.

\section{Exclusion criteria}

- All patients who did not undergo caesarean section at the Federal Medical Centre, Yenagoa but were managed following referral from another health care facility post-caesarean section were excluded from the study.

\section{Data collection}

Labour ward, theatre, and postnatal ward records were used to retrieve data on the 1,654 women who had caesarean sections during the study period. Variables collected for the study included patient's age, parity, gestational age, booking status, indication for caesarean 
section, category of caesarean section, Apgar score, maternal outcome etc.

\section{Statistical analysis}

Statistical analysis of the data obtained was done using Statistical Package for Social Sciences (SPSS) version 22. The results are presented in tables, frequencies and percentages.

\section{RESULTS}

Over the study period, there were a total of 5,793 deliveries and 1,654 of them were by caesarean section.
The caesarean section rate increased from $27.5 \%$ in 2013 to $30.6 \%$ in 2014 , then to $31 \%$ in 2015 , thereafter it decreased to $29.8 \%$ in 2016 and further decreased to $21.4 \%$ in 2017 . The average caesarean section rate over the study period was $28.6 \%$. Age of patients ranged from 15 years to 52 years. Table 1 shows the age distribution of patients. Most patients were aged 25-29 years (31.6\%), while just one patient $(0.1 \%)$ was above 49 years. The mean age was $30.13 \pm 5.1$ years. Most $(86.9 \%)$ of the pregnancies were term, $7.4 \%$ were preterm, $3.8 \%$ were late term and $1.9 \%$ were post term. Most of the patients were booked (62.8\%), leaving 37.2\% un-booked patients. Most of the patients who had caesarean section in this study were previously multiparous $(40.4 \%)$ as shown in Table 2.

Table 1: Age range of patients who delivered by caesarean section.

\begin{tabular}{|llllll|}
\hline \multicolumn{1}{|l}{ Age (years) } & Frequency & Percent & Valid percent & Cumulative percent \\
\hline \multirow{5}{*}{} & 73 & 4.4 & 4.4 & 4.4 \\
\cline { 2 - 6 } & $15-19$ & 36 & 2.2 & 2.2 & 6.6 \\
\cline { 2 - 6 } Valid & 168 & 10.2 & 10.2 & 16.7 \\
\cline { 2 - 6 } & $20-24$ & 522 & 31.6 & 31.6 & 48.3 \\
\cline { 2 - 6 } & $30-29$ & 517 & 31.3 & 31.3 & 79.6 \\
\cline { 2 - 6 } & $35-39$ & 288 & 17.4 & 17.4 & 97.0 \\
\cline { 2 - 6 } & $40-44$ & 45 & 2.7 & 2.7 & 99.7 \\
\cline { 2 - 6 } & $45-49$ & 4 & 0.2 & 0.2 & 99.9 \\
\hline
\end{tabular}

Table 2: Parity of patients who delivered by caesarean section.

\begin{tabular}{|c|c|c|c|c|c|}
\hline Parity & & Frequency & Percent & Valid percent & Cumulative percent \\
\hline \multirow{5}{*}{ Valid } & Grand multiparous & 143 & 8.6 & 9.1 & 9.1 \\
\hline & Multiparous & 632 & 38.2 & 40.4 & 49.5 \\
\hline & Nulliparous & 311 & 18.8 & 19.9 & 69.4 \\
\hline & Primiparous & 479 & 29.0 & 30.6 & 100.0 \\
\hline & Total & 1565 & 94.6 & 100.0 & \\
\hline Missing & System & 89 & 5.4 & & \\
\hline Total & & 1654 & 100.0 & & \\
\hline
\end{tabular}

Most $(81.8 \%)$ of the women had a primary caesarean section while $18.2 \%$ of them had a repeat caesarean section. Cephalopelvic disproportion (CPD) was the most common indication for caesarean section (26.6\%), followed by previous caesarean section (18.2\%), suspected fetal distress (11.2\%), severe preeclampsia/eclampsia with unfavourable cervix (7.9\%), obstructed labour (6\%), and breech presentation (5.9\%). Other indications for caesarean section in this study are shown in Table 3. Emergency and urgent caesarean sections constituted $81.3 \%$ of caesarean sections and $18.7 \%$ were elective caesarean sections. Apart from suspected fetal distress which was the most common indication for emergency caesarean section (62.8\%), other common indications were abruptio placentae $(11.8 \%)$, placenta previa $(8 \%)$, cord prolapse $(5.2 \%)$, and previous caesarean section $(3.1 \%)$.

The commonest indication for urgent caesarean section was CPD (41.9\%), followed by severe preeclampsia/eclampsia with unfavourable cervix $(12.1 \%)$, previous caesarean section $(10.3 \%)$, obstructed labour $(9 \%)$, breech presentation $(5.5 \%)$, and poor progress in labour $(5.3 \%)$. Other relatively common indications were failed induction of labour (3.2\%), and abnormal lie and presentation (2.2\%). Over half (59.2\%) 
of elective caesarean sections were in women with previous caesarean sections. Otherwise, elective caesarean sections were commonly done for breech presentation $(12.2 \%)$, suspected fetal macrosomia $(6.6 \%)$, prevention of mother to child transmission of human immunodeficiency virus (HIV) (5.6\%), abnormal lie and presentation $(4.3 \%)$, and other relatively common indications like twin and higher order multiple pregnancies $(2.6 \%)$, maternal request $(2.3 \%)$, and placenta previa $(2 \%)$.

Table 3: Indications for caesarean section.

\begin{tabular}{|c|c|c|c|c|}
\hline \multicolumn{2}{|c|}{ Indications } & Frequency & Percent & Valid percent \\
\hline \multirow{20}{*}{ Valid } & Cephalopelvic disproportion & 430 & 26.0 & 26.6 \\
\hline & Previous caesarean section & 295 & 17.8 & 18.2 \\
\hline & Suspected fetal distress & 182 & 11.0 & 11.2 \\
\hline & Severe preeclampsia/eclampsia with unfavourable cervix & 128 & 7.7 & 7.9 \\
\hline & Obstructed labour & 97 & 5.9 & 6.0 \\
\hline & Breech presentation & 95 & 5.7 & 5.9 \\
\hline & Poor progress in labour & 56 & 3.4 & 3.5 \\
\hline & Placenta previa & 43 & 2.6 & 2.7 \\
\hline & Abnormal lie and presentation & 41 & 2.5 & 2.5 \\
\hline & Suspected fetal macrosomia & 36 & 2.2 & 2.2 \\
\hline & Abruptio placentae & 34 & 2.1 & 2.1 \\
\hline & Failed induction of labour & 33 & 2.0 & 2.0 \\
\hline & Twin and higher order multiple pregnancies & 30 & 1.8 & 1.9 \\
\hline & $\begin{array}{l}\text { Prevention of mother to child transmission of human } \\
\text { immunodeficiency virus (HIV) }\end{array}$ & 20 & 1.2 & 1.2 \\
\hline & Severe oligohydramnios & 18 & 1.1 & 1.1 \\
\hline & Cord prolapse & 15 & .9 & .9 \\
\hline & Delayed second stage of labour & 11 & .7 & .7 \\
\hline & Maternal request & 7 & .4 & .4 \\
\hline & Others* & 47 & 2.8 & 2.9 \\
\hline & Total & 1618 & 97.8 & 100.0 \\
\hline Missing & System & 36 & 2.2 & \\
\hline Total & & 1654 & 100.0 & \\
\hline
\end{tabular}

Table 4: Fetal outcome according to category of caesarean section.

\begin{tabular}{|c|c|c|c|c|}
\hline \multirow[b]{2}{*}{ Fetal outcome } & \multicolumn{3}{|c|}{ Category of caesarean section } & \multirow[b]{2}{*}{ Total } \\
\hline & $\begin{array}{l}\text { Emergency (category 1) } \\
\text { caesarean section }\end{array}$ & $\begin{array}{l}\text { Urgent (category 2) } \\
\text { caesarean section }\end{array}$ & $\begin{array}{l}\text { Elective (category 4) } \\
\text { caesarean section }\end{array}$ & \\
\hline \multirow{2}{*}{ Still birth } & 6 & 80 & 0 & 86 \\
\hline & $2.0 \%$ & $8.0 \%$ & $0.0 \%$ & $5.4 \%$ \\
\hline \multirow{2}{*}{ Low apgar score } & 34 & 7 & 0 & 41 \\
\hline & $11.4 \%$ & $0.7 \%$ & $0.0 \%$ & $2.6 \%$ \\
\hline \multirow{2}{*}{$\begin{array}{l}\text { Moderately abnormal apgar } \\
\text { score }\end{array}$} & 49 & 57 & 6 & 112 \\
\hline & $16.5 \%$ & $5.7 \%$ & $2.0 \%$ & $7.0 \%$ \\
\hline \multirow{2}{*}{ Reassuring apgar score } & 208 & 850 & 295 & 1353 \\
\hline & $70.0 \%$ & $85.5 \%$ & $98.0 \%$ & $85.0 \%$ \\
\hline \multirow{2}{*}{ Total } & 297 & 994 & 301 & 1592 \\
\hline & $100.0 \%$ & $100.0 \%$ & $100.0 \%$ & $100.0 \%$ \\
\hline
\end{tabular}

CPD was also the most common indication for caesarean section among un-booked women (28.7\%). Others are obstructed labour (14.6\%), suspected fetal distress $(12.1 \%)$, severe preeclampsia/eclampsia with 
unfavourable cervix $(10.9 \%)$, previous caesarean section $(8 \%)$, and breech presentation $(5.8 \%)$. Higher incidences of CPD occurred in primiparous women $(10.2 \%)$ and multiparous women (7.9\%), compared to nulliparous women (7.3\%), with a slightly higher proportion occurring in the unbooked women $(28.7 \%)$ compared to booked women $(25.3 \%)$. Most of the babies delivered by caesarean section had reassuring Apgar scores (85\%), 7.1\% had moderately abnormal Apgar scores, $2.6 \%$ had low Apgar scores, and 5.4\% were still births. Low and moderately abnormal Apgar scores were commoner in babies delivered by emergency caesarean section (Table 4). Most $(71.5 \%)$ of the babies delivered by emergency caesarean section following suspected fetal distress had reassuring Apgar scores, $19.8 \%$ had moderately abnormal Apgar scores and $8.7 \%$ had low Apgar scores. There were 3 maternal deaths following caesarean sections in the study period giving a case fatality rate of $0.18 \%$.

\section{DISCUSSION}

The caesarean section rate of $28.6 \%$ from this study is slightly higher than rates from similar studies of $25.6 \%$ and $27.6 \%$ recorded in teaching hospitals in Calabar and Enugu respectively, and slightly lower than the $30.3 \%$ recorded from a similar study in another teaching hospital in Port Harcourt. ${ }^{12-14}$ These are tertiary level health facilities in the south of Nigeria like the study centre that possibly share the same peculiarities in terms of population being served, and hospital capability. The comparable caesarean section rates though with slight variation is a ground to encourage further studies that would purposefully assess and compare caesarean delivery across these institutions in line with WHO recommendation, and highlight relevant local/regional clinical and nonclinical modifiable indications for caesarean delivery. ${ }^{34}$ The trend observed in the age distribution of patients showing that most of the patients that delivered by caesarean section were within the 25-29 years age range and followed by the 30-34 years age range is similar to what also obtained in studies done in other centres in the south-south, south-east, north-west regions of Nigeria and the federal capital territory. ${ }^{12,13,14,17,18}$ However, unlike most of these other studies where the 20-24 years age range followed after the above mentioned age ranges, the 35-39 years age range was what followed in this study with the 20-24 years age range being the fourth common. This trend may explain why most of the patients who delivered by caesarean section in this study were multiparous and different from what was reported in most of the other studies with similar pattern of patient age, where most of the women were primigravida except in Sokoto where most of the women were not primigravida but were also of lower parity (primiparous). ${ }^{12-14,17,18}$

There were more booked than unbooked women in this study because apart from the study centre being a referral hospital where poorly managed and complicated labour cases (usually from traditional birth attendants and patients who cannot afford the cost of caesarean section in private hospitals) are referred to, it also caters for patients who primarily receive antenatal care in the facility. The patients that receive antenatal care in the study centre are a mix of low and middle social classes. Some of those of low social class usually avoid delivering in the centre for reason of cost and end up being referred to the centre when a complication arises.

Most of the caesarean sections in this study were done as an emergency or an urgent caesarean section. Cephalopelvic disproportion was the most common indication for caesarean section, the same as what was reported in Gwagwalada, Port Harcourt, Calabar, and Maiduguri. ${ }^{12,13,18,21}$ Previous caesarean section was however the most common indication for caesarean section in Enugu, Nnewi, Zaria, and Shagamu. ${ }^{14,15,19,24}$ Beyond the most common, and just as it was found in studies done in Port Harcourt, Calabar, Enugu, Nnewi, and Abakaliki, the leading indications for caesarean section were among the following: cephalopelvic disproportion, previous caesarean section, fetal distress, hypertensive disorders in pregnancy, obstructed labour, breech presentation, antepartum haemorrhage, suspected fetal macrosomia, prolonged labour/poor progress in labour and failed induction of labour. ${ }^{12-16}$ Similar patterns were reported from the studies done in Sokoto, Gwagwalada, Zaria, Gombe, Maiduguri, Birnin Kebbi, Birnin Kudu, Sagamu, Lagos, Awka and Jos. ${ }^{17-26,28}$ It was found that, among the leading indications for elective caesarean section in this study were previous caesarean section, breech presentation, suspected fetal macrosomia, abnormal lie and presentation, and twin and higher order multiple pregnancies which are a common trend. Some $(5.6 \%)$ of the elective caesarean sections were done for prevention of mother to child transmission of HIV; this is relatively high, close to the $7.34 \%$ reported in Calabar and reflective of the prevalence of HIV in the south-south region of the country. ${ }^{13}$

Most of the indications for caesarean section from this study are not absolute indications; they are modifiable and therefore offer an opportunity to avoid caesarean section while still staying within safety limits. Another $2.3 \%$ of elective cesarean sections were done for maternal request which is higher than the $1.5 \%$ reported in Enugu. ${ }^{14}$ Older primigravida constituted $42.9 \%$ of these women, and another $42.9 \%$ were primiparous and aged between 20 and 34 years. Coleman et al in a literature review on caesarean delivery on maternal requests stated that age was noted as an important risk factor and the benefits of caesarean delivery on maternal request may outweigh the risks in older women, however caesarean delivery on maternal request is not recommended for women desiring several children. ${ }^{36}$ In this study, low and moderately abnormal Apgar scores were more associated with emergency and urgent caesarean sections. According to the American College of Obstetricians and Gynecologists and the American Academy of pediatrics, Apgar score is an accepted and convenient method of 
reporting the status of the newborn infant immediately after birth and the response to resuscitation if needed. ${ }^{37} \mathrm{~A}$ low Apgar score at 5 minutes or more is a nonspecific sign of illness and may be the first indication of encephalopathy, but alone it is not a specific indicator for intrapartum compromise. It is inappropriate to use Apgar score alone to diagnose asphyxia, and Apgar scores do not predict individual mortality or neurological outcome. It was found that most of the babies delivered by caesarean section done for suspected fetal distress showed no sign of distress at birth with reassuring Apgar scores. This suggests that suspected fetal distress is a modifiable indication for caesarean section with more room for research. The still births in this study were intrauterine fetal deaths diagnosed preoperatively but with coexisting or emerging indications for caesarean section. Addressing the decline in the practice of operative vaginal deliveries including destructive operations as alternatives to caesarean section is relevant to efforts to reduce unnecessary caesarean sections in developing countries. ${ }^{38,39}$

\section{CONCLUSION}

The caesarean section rate of $28.6 \%$ in this study is comparable (with only a slight variation) with rates that have been reported in studies done in teaching hospitals within south-south geopolitical zone of Nigeria. This trend exists while the population level caesarean section rate in Nigeria is much lower at $2 \%$, implying that while a lot of women still lack access to caesarean section to save their lives and that of their babies, some might be undergoing unnecessary procedures. The leading indications for caesarean section in this study are modifiable, giving room for implementation of interventions to reduce unnecessary caesarean sections. There are compelling reasons to increase access to caesarean section across the population in Nigeria and other countries in Sub-Saharan Africa. There are also compelling reasons to reduce unnecessary caesarean sections within the same setting of low- and middleincome countries. Efforts to achieve these goals can go on concurrently. Collaborative research between institutions is required to assess peculiar regional determinants of caesarean section towards developing suitable interventions to reduce unnecessary caesarean sections at regional level. WHO more recently proposed the Robson classification as a more action-oriented classification system that can be used to compare caesarean section rates across hospitals, to guide implementation of interventions needed to optimize the use of caesarean section at hospital level, and to monitor effectiveness of such interventions. Further studies are therefore required on caesarean section using the Robson classification.

Funding: No funding sources Conflict of interest: None declared Ethical approval: Not required

\section{REFERENCES}

1. Boley JP. The history of caesarean section. Can Med Assoc J. 1991;145(4):319-21.

2. World Health Organization. Monitoring emergency obstetric care: a handbook, 2009. Available at: https://apps.who.int/iris/handle/10665/44121.

Accessed on $15^{\text {th }}$ November 2019.

3. Souza JP, Gulmezoglu AM, Lumbiganon P, Laopaiboon M, Carroli G, Fawole B, et al. Caesarean section without medical indications is associated with an increased risk of adverse short-term maternal outcomes: the 2004-2008 WHO Global Survey on Maternal and Perinatal Health. BMC Med. 2010;8:71.

4. Gupta M, Saini V. Caesarean section: mortality and morbidity. JCDR. 2018;12(9):1-6.

5. Sobhy S, Arroyo-Manzano D, Murugesu N, Karthikeyan G, Kumar V, Kaur I, et al. Maternal and perinatal mortality and complications associated with caesarean section in low-income and middle-income countries: a systematic review and meta-analysis. Lancet. 2019;393:1973-82.

6. Betran AP, Torloni MR, Zhang JJ, Gulmezoglu AM for the WHO working group on caesarean section. WHO Statement on caesarean section rates. BJOG. 2016;123:667-70.

7. World Health Organization. WHO Statement on caesarean section rates, 2015. Available at: https://www.who.int/reproductivehealth/publications /maternal_perinatal_health/cs-statement/en/. Accessed on $15^{\text {th }}$ November 2019.

8. Betran AP, Ye J, Moller A-B, Zhang J, Gulmezoglu $\mathrm{AM}$, Torloni MR. The increasing trend in caesarean section rates: Global, regional and national estimates: 1990-2014. PLoS One. 2016;11(2):e0148343.

9. Feng XI, Xu L, Guo Y, Ronsmans C. Factors influencing rising caesarean section rates in China between 1988 and 2008. Bull World Health Organ. 2012;90:30-39A.

10. Lauer JA, Betrán AP, Merialdi M, Wojdyla D. Determinants of caesarean section rates in developed countries: supply, demand and opportunities for control. World Health Report. 2010;29:1-22.

11. Betran AP, Temmerman M, Kingdon C, Mohiddin $\mathrm{A}$, Opiyo $\mathrm{N}$, Torloni $\mathrm{MR}$, et al. Interventions to reduce unnecessary caesarean sections in healthy women and babies. Lancet. 2018;392:1358-68.

12. John CO, Alegbeleye JO. Caesarean delivery at a teaching hospital, south-south Nigeria: a five-year review. IJTDH. 2017;21(2):1-6.

13. Njoku CO, Emechebe CI, Edet EE, Oyama SE, Iklaki CU. The trend, determinants and maternal outcome of caesarean section at the university of Calabar teaching hospital, Calabar, Nigeria; a 5 year appraisal. IOSR-JDMS. 2016;15(12):75-9.

14. Ugwu EOV, Obioha KCE, Okezie OA, Ugwu AO. A five-year survey of caesarean delivery at a Nigerian tertiary hospital. Ann Med Health Sci Res. 2011;1(1):77-84. 
15. Eleje GU, Udigwe GO, Akabuike JC, Eke AC, Eke NO, Umeobika JC. The rate of caesarean section in Nnewi, Nigeria: a 10-year review. Afrimedic J. 2010;1(1):11-4.

16. Onoh RC, Eze JN, Ezeonu PO, Lawani LO, Iyoke CA, Peter ON. A 10-year appraisal of caesarean delivery and the associated fetal and maternal outcomes at a teaching hospital in southeast Nigeria. IJWH. 2015;7:531-8.

17. Daniel CN, Singh S. Caesarean delivery: An experience from a tertiary institution in north western Nigeria. Niger J Clin Pract. 2016;19:18-24.

18. Isah $\mathrm{AD}$, Adewole $\mathrm{N}$, Zaman J. A five-year survey of caesarean delivery at a Nigerian tertiary hospital. Trop J Obstet Gynaecol. 2018;35:14-7.

19. Adelaiye SM, Olusanya A, Onwuhafua PI. Caesarean section in Amhadu Bello University teaching hospital Zaria, Nigeria: A five-year appraisal. Trop J Obstet Gynaecol. 2017;34:34-8.

20. Takai IU, Bah AM, Bukah M, Ugwa EA, Gaya SA. Caesarean delivery in a tertiary health institution in north-eastern Nigeria: A 5 year-review. Trop J Obstet Gynaecol. 2015;32(2):21-7.

21. Geidam AD, Audu BM, Kawuwa BM, Obed JY. Rising trend and indications of caesarean section at the university of Maiduguri teaching hospital, Nigeria. Ann Afr Med. 2009;8(2):127-32.

22. Ugwa E, Ashimi A, Abubakar MY. Caesarean section and perinatal outcomes in a sub-urban tertiary hospital in north-west Nigeria. Niger Med J. 2015;56:180-4.

23. Nwobodo EI, Wara HL. High caesarean section rate at Federal Medical Centre, Birnin-Kebbi: Real or apparent? Niger Med Pract. 2004;46(2):39-40.

24. Akadri AA, Odelola OI. A six-year review of caesarean sections at Olabisi Onabanjo University Teaching Hospital Sagamu, south west Nigeria. Niger Med Pract. 2017;71(3-4):53-7.

25. Akinola OI, Fabamwo AO, Tayo AO, Rabiu KA, Oshodi YA, Alokha ME. Caesarean section - an appraisal of some predictive factors in Lagos Nigeria. BMC Preg Childbirth. 2014;14:217.

26. Ikeako LC, Nwajiaku L, Ezegwui HU. Caesarean section in a secondary health hospital in Awka, Nigeria. Niger Med J. 2009;50:64-7.

27. Osonwa OK, Eko JE, Ekeng PE. Trends in caesarean section at Calabar General Hospital, Cross River State, Nigeria. EJBMSR. 2016;4(1):1-5.

28. Sule HM, Hassan ZI, Shambe IH. Caesarean section rate and its indications in an urban private hospital in Jos, north central Nigeria: A 15-year survey. IOSRJDMS. 2017;16(6):88-92.
29. Adewuyi EO, Auta A, Khanal V, Tapshak SJ, Zhao Y. Caesarean delivery in Nigeria: prevalence and associated factors - a population-based crosssectional study. BMJ Open. 2019;9:e027273.

30. Thomas S, Meadows J, McQueen KAK. Access to caesarean section will reduce maternal mortality in low-income countries: a mathematical model. World J Surg. 2016;40(7):1537-41.

31. Irani $\mathrm{M}$, Deering $\mathrm{S}$. Challenges affecting access to caesarean delivery and strategies to overcome them in low-income countries. Int $\mathbf{J}$ Gynaecol Obstet. 2015;131(1):30-4.

32. Kingdon $\mathrm{C}$, Downe $\mathrm{S}$, Betran AP. Interventions targeted at health professionals to reduce unnecessary caesarean sections: a qualitative evidence synthesis. BMJ Open. 2018;8:e025073.

33. Chen I, Opiyo N, Tavender E, Mortazhejri S, Rader $\mathrm{T}$, Petkovic J, et al. Non-clinical interventions for reducing unnecessary caesarean section. Cochrane Database Syst Reviews. 2018;9:CD005528.

34. World Health Organization. WHO recommendations: non-clinical interventions to reduce unnecessary caesarean sections, 2019. Available at: https://www.who.int/reproductivehealth /publications/non-clinical-interventions-to-reducecs/en/. Accessed on $15^{\text {th }}$ November 2019.

35. Spong CY, Berghella V, Wenstrom KD, Mercer BM, Saade GR. Preventing the first caesarean delivery. Obstet Gynecol. 2012;120:1181-93.

36. Coleman VH, Lawrence H, Schulkin J. Rising caesarean delivery rates: The impact of caesarean delivery on maternal request. Obstet Gynecol Surv. 2009;64(2):115-9.

37. American College of Obstetricians and Gynecologists, American Academy of paediatrics. The Apgar score. Committee opinion No. 644. American College of Obstetricians and Gynecologists. Obstet Gynecol. 2015;126:e52-5.

38. Anozie OB, Osaheni LL, Onu FA, Onoh RC, Ogah EO, Eze JN, et al. Declining rate of operative vaginal deliveries in Nigeria. OJOG. 2018;8(3):175-84.

39. Unuigbe JA, Agbon-Ojeme GE, Erthatiemwonmon RA, Maduako KT. Instrumental vaginal deliveries: A review. Trop J Obstet Gynaecol. 2018;35:99-107.

Cite this article as: Osegi N, Makinde OI. Towards optimizing caesarean section: a five-year review of caesarean sections at a Southern Nigeria hospital. Int J Reprod Contracept Obstet Gynecol 2020;9:205-11. 